\title{
Rhetorical Analysis of Hate Speech: Case Study of Hate Speech Related to Ahok's Religion Blasphemy Case
}

\author{
Kurnia Arofah \\ Department of Communication Science, Faculty of Social and Political Sciences, University of \\ Pembangunan Nasional "Veteran" Yogyakarta \\ Email: kurnia.arofah@upnyk.ac.id
}

\begin{abstract}
The discussion about hate speech is not something new. However, recently it becomes phenomenon that widely spoken. As something that naturally comes out as a human nature. Nowadays hate speech tends to be harmful because it is supported by new media such as online media and social media. This research try to discuss about hate speech related to religion blasphemy accusation that drags, Basuki Tjahaya Purnama known as Ahok into jail. This paper used qualitative method and rhetoric analysis to analyze the hate speech in online media news related to Ahok's case. The results are, hate speech came from content posted in website such as online political opinion and news. From ethos aspect, most of the hate speech neglected the ethos aspect which provides the credibility and trustworthiness of the source.; from the pathos aspect, the author of the news are choosing words that triggered anger and negative emotion from its audience; from the logos aspect, most of the hate speech draws it's readers to logical fallacy due to the lackness of facts of its conclusion claim. The Hate speech rhetoric neglects the ethos and logos aspects and it mostly rely on pathos aspect to persuade its readers for hating.
\end{abstract}

Keywords : hate speech, rhethorical analysis, religion blasphemy

\begin{abstract}
Abstrak. Diskusi mengenai ujaran kebencian bukanlah hal baru. Namun belakangan ini menjadi fenomena yang banyak dibicarakan. Sebagai sesuatu yang muncul dari sifat alamiah manusia, saat ini ujaran kebencian cenderung berbahaya karena penyebarannya didukung media baru seperti media online dan media sosial. Penelitian ini berusaha mendiskusikan ujaran kebencian terkait penistaan agama yang menyebabkan Basuki Tjahaya Purnama, atau Ahok masukpenjara. Makalah ini menggunakan metode penelitian kualitatif dan analisis retorika untuk menganalisis pemberitaan di media online yang terkait dengan kasus Ahok. Hasilnya, dari aspek ethos, sebagian besar ujaran kebencian mengabaikan aspek ethos yang menyediakan kredibilitas dan keterpercayaan sumber; dari aspek pathos, penulis berita tersebut memilih kata-kata yang memicu kemarahan dan emosi negatif dari khalayaknya; dari aspek logos, sebagian besar ujaran kebencian menyebabkan khalayaknya terjeruus kedalam sesat pikir karena memberikan kesimpulan uang tidak diduking dengan bukti kuat. Ujaran kebencian mengabaikan aspek ethos dan logos dan kebanyakan mengandalkan apek pathos untuk membujuk pembacanya agar membenci.
\end{abstract}

Kata kunci: ujaran kebencian, analisis retorika, penistaan agama 


\section{INTRODUCTION}

Recently, in almost every part of the world, including Indonesia, the term of hate speech becomes much publicized. In the last two or three years, while freedom of speech is protected and guaranteed by Indonesian government, the harm of hate speech that resulted from freedom of speech is emerging. It is easy for us to find the form of hate speech especially in online media. According to oxford dictionary, hate speech is abusive of threatening speech or writing that expresses prejudice against a particular group, especially on the basis of race, religion, or sexual orientation.

The United Nations Educational, Scientific \& Cultural Organization (UNESCO) stated that hate speech is the expression of conflict between different groups within and across societies. More specific, hate speech could be concluded as bias motivated, hostile, malicious speech aimed at a person or a group of people because of their actual or perceived innate characteristics, intended to injure, dehumanize, harass, intimidate, also victimize against targeted groups (Cohen-Almagor, 2011).

Hate is something that naturally arises from aggressive human nature, evolves from an ancient survival instinct (Whillock, 2000; Sternberg, 2008). Hate has various alternative definitions and it is indeed a complex phenomenon (Stenberg, 2008). Fortunately, the society has way of teaching its members how to channel this aggressiveness in approved way (Whillock, 2000). Hate and hate speech could be channeled in many ways. Nowadays, hates speech spreading through social media are rapidly increased and potentially reach much larger audience than extremist print media were able to reach previously. Hate speech implies the complex balance between fundamental rights and principles such as freedom of expression and the defense of human dignity (Gagliardone et al, 2015).

In Indonesia where its society consists of diverse race, religion, beliefs and ethnicity, nowadays hate speech is spreads easily like wild fire through online media mostly facilitated by websites and social media such as Facebook and twitter. Within 2016, hate speech including defamation, harassment, slander, provocation, and threats against individuals or groups especially the one that covering race and religion was the most frequently reported Internet crime in Indonesia. There are 199 cases reported (Newsdesk, 2017).

The most heated hate speech argument that divides and brings Indonesian society into conflict is hate speech related to religion blasphemy which dragged Basuki Tjahaya Purnama (Ahok) while campaigning his candidacy in Jakarta's Governor Election, 2017. In Indonesia, blasphemy considered as an important aspect of social and political spectra, where the diversity of beliefs in the country protected by Delik Penistaan Agama (Blasphemy law) in Indonesian Criminal Code. In Indonesia, religion affects the reaction of voters to candidate and often used as weapon to attack someone during political election, even if its only verbal attack in social media or online media.

During past decade, the usage of online media in Indonesia rapidly increased in line with the penetration of Internet in Indonesia, supported by the growth of smartphone ownership by Indonesian Citizen (APJII, 2016). In several areas especially big cities or urban areas in Indonesia, the usage of Internet and social media slowly shift the behavior of audience in consuming news. Online and social media become news sources that chosen by audience over old or radio (Ambardi et.al , 2014). People nowadays rely on online media to meet their needs of information. 
However, in accordance to the needs of information through online media, nowadays-online media industry in Indonesia littered with various online media with diverse basic theme and topic. One of the most prominent basic themes for online media in Indonesia is the one related to religion. Muhammad Machasin, previous General Director of Bimas Islam Ministry of Religious Affair of Indonesia stated, recently there is numerous news from online media that gives unbalance coverage of information as it cornering one side or party, provoking and alluring readers to the wrong direction. According to his data, there are more than 20.000 sites with content that didn't give any virtues to its reader, yet provoke negative emotion instead. While, the one that gives virtues and inspire it readers to think are no more than 1000 (Nurdin/Zunus, 2016).

However, it was only 22 sites/ websites promoting radicalism blocked by Ministry of Communication and Information of Indonesia in 2015 (www.kominfo.go.id, 2015). While in middle 2016, there are 24 sites blocked because having negative content such as: a. indicated with radicalism and its supporters; b. violating the law due to inaccuracy of news; c. having content related to ethnicity, race and religion; $d$. hate speech, slander and provocation; and e. harassing nation's symbol These sites and websites violating Indonesian Law of Internet and and Electronic Transaction (UU ITE), article 28, subsection 2 that stated "Every person who intentionally and without rights, spreading information to create hatred or hostility among certain individuals and/or groups of society based on ethnicity, race, and inter-community (SARA) will be jailed for 6 years or fined with Rp. 1 billion as penalty.

By the end of 2017, the blocked sites reached 27.000 sites, including the sites with radicalism but mostly the one with pornography content.
However, Rudiantara, The Minister of Communication and Information of Indonesia said that after 100 sites blocked, another 1000 will rise a day after. It indicates that there are many other sites with radicalism and hate content are reborn after blocked which is still not in the watch list by The National Agency for Combating Terrorism of Indonesia and out from filtering system by Ministry of Communication and Information of Indonesia.

This issue is important to be studied because it has sociological, political, ethical, and psychological aspect that affects the mental social development of Indonesian society that consist of very diverse ethnical, race, religion, and beliefs background. Many hate speech cases related to religion shows how Internet in Indonesia are used by netizen to relay messages consist of hateful language that release anger mostly in form of agitation. The most significant damage that brought by hate speech is it sends ripples of fear and tension across community and often words that deliver in hate manner are the precursors of action (Whillock, 2000).

Hate speech is easy to find in political practices, mostly during the campaign of political candidate before election. In this occasion, hate messages become arguments for the rhetorical annihilation of the opponent (Willock, 2000). In mid 2016 to mid 2017, during the election of Jakarta Governor, there are so many hate speech spread in the Internet through websites that could be considered as hate sites during the campaign period. This situation was much worse because Ahok, one of governor candidate, involved with religion blasphemy accusation related to his speech in Seribu Island during his campaign. During his speech, Ahok accused his opponents us Koran verse in order to trick people not voting for him.

After Ahok's speech, Indonesian 
were as if split into several poles, there are the one who supports Ahok, other are against his action and the other is neither supporting or against him. There are even two big protest act in Jakarta, to demand the government to prosecute and imprisoned Ahok The first protest were held in November, 4th, 2016 which reported by Republika daily newspaper attended by 7,5 million protester (pratiwi \& Fuji, 2016)., while Britain media, the Guardian reported it only 200.000 protester (Agence France-Presse, 2016). The second protest was held in December 12, 2016 with the same demand.Those protests running along both with the campaign for Jakarta's Governor election and the investigation for Ahok's religion blasphemy accusation.

Religion blasphemy is not a new case in Indonesia. According to Amnesty International, until 2014, there are 5 cases related to religion blasphemy that makes it blasphemer end up in court and jailed. Two of them are accused for the hate speech. First is Sebastian Joe who allegedly posted statement on Facebook, which insulted Islam. Second is Alexander An who imprisoned after posting statements and pictures on his personal Facebook site and on the 'Minang Atheist' Facebook group that perceived by many as insulting Islam and the prophet Muhammad (Amnesty International, 2017).

Both cases show that nowadays online and social media become a new place to spread and breed hatred. New media gives a great deal of opportunity for public to talk, publish, educate them self to a certain issue (Flew, 2008). Online media also has the advantage of new media characteristic. It cut the traditional media pathway, avoiding gatekeeping and government censorship. This is why nowadays, according to NU Online director, Syafiq Alielha, the growth of online media that used as the will of its owner to spread hate and radicalism in the name of religion is abundant. To make it worse, this online media that could be categorized as 'hate site' has relatively high visitors traffic (yayasan tifa, -).

During the period of campaign and while waiting for the investigation and trial, which finally verdict Ahok to be jailed for two years, there were a lot of websites that echoes hate speech toward Ahok, provoking the negative emotion of audience. This news was written in online media then spread through social media such as Facebook and Twitter, also meme posting through Instagram. During this campaign, the war of information, opinion and news in the Internet were so intense between the one who supporting Ahok and the one who against him. Many supporters of each sides coining new terms for insulting the opposed sides such as calling Ahok with term 'mulut jamban' (toilet mouth) , 'kafirun dan munafikun' (infidel and hypocrite), 'cebong' (tadpole), 'bani serbet' (sons of napkins) and many other terms (Franciska, 2017)

These terms are spreading along the provocation to hate each side mostly in the news that posted by sites that supporting or against Ahok's case related to religion blasphemy accusation. Most of the sites were then blocked while some of its contents are copy-pasted by other sites, and some of them are still exist. These sites and website could be considered as 'hate site' which defined as the site that caries a hateful message in any form of textual, visual, or audio based rhetoric (Cohen-Almagor, 2011).

While rhetoric is the study and art of writing and speaking well, being persuasive, and knowing how to compose successful writing and presentation (clas.iuowa.edu), hate speech it self is a genre of rhetoric that evokes negative emotions, attitudes and opinions among specific groups of people, and promotes intolerance (Nilsen, 2014). Rhetorical 
messages always occur in a specific situation or context and media is one of the most important places where rhetorical analysis needs to happen, because Rhetoric or the way language and image persuades is things that makes media work (Caroll, 2010).

Based on this background, this paper will discuss hate speech used in the content posts by websites which could be categorized as sites that has promoting hate content related to religion blasphemy case that involved Ahok using rhetorical analysis. According to Selzer (2003), there is no generally accepted definition of rhetorical analysis because there are really no generally accepted definitions of rhetoric itself. However, most rhetorical analysis applied Aristoteles's Trichotomy of rhetoric: Ethos, Pathos Logos

Ethos is the features of a text which are related to credibility of the speaker, Pathos is the persuasive arguments which are mainly derived from the values held by a community, and logos refers to solid reason emerging from intellectual thinking (Irajzad et al, 2017). Rhetorical analysis could be use to understand how certain ideas and attitudes conveyed through spoken or written message with a special focus on the methods of persuasion, and it might be helpful to think rhetorical analysis as a kind of critical reading (Selzer, 2013).

\section{METHOD}

This research objective was to describe the hate speech rhetoric content posted in the websites especially the sites that could be categorized, as sites that promotes hate content related to religion blasphemy case that involved Ahok. Qualitative approach used in this research. Qualitative research was applied to express a commitment to viewing events and the social world through the eyes of people studied. This paper uses the rhetoric framework to analyze the hate speech.

As rhetorical message, hate speech has three components: ethos, pathos, and logos (Hansen, 2003):

\section{Ethos}

Mostly related to credibility or the authority of the speaker or writer that is capable of being believed. Ethos is not created or bound to the author, but is embedded in the message or argument.

2. Logos

Related to rationale, logical and argumentative discourse, and related to the messages of rhetoric's. Logos described as proofs that embedded within the message. It includes fact and proofs from scientific point of view that unbiased and subjective.

\section{Pathos}

Related directly to the audience. Pathos is the arousing of emotions in the audience. Pathos relies on evoking emotional reaction from the audience mostly by emphasizing phrases or situation

To make the best argument, these three components cannot be separated. To persuade the audience, rhetoric whether it's for good or bad purposes and whether it is intended or unintended, the speaker must have good credibility. The messages that relayed must be logically valid, and the speaker must understand the audience

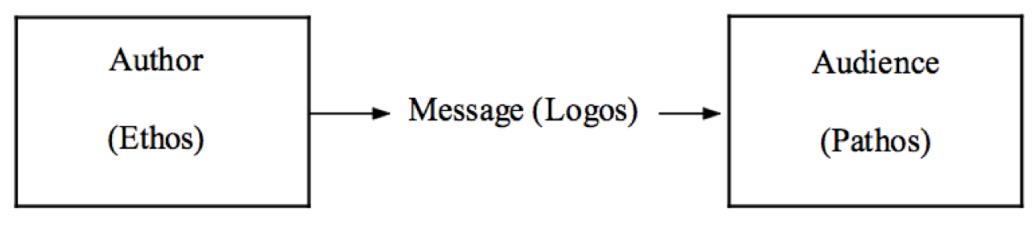

FIGURE 1. The Linear Rhetorical Flowchart by Jacob Wisse (1989) (Hansen, 2003) 
emotion.

The sample used in this research was gathered through convenience sampling. Convenience sampling is non-probability or nonrandom sampling where members of the target population meet certain practical criteria such as easy accessibility, geographical proximity, availability at a given time, or the willingness to participate are included for the purpose of the study. The main assumption associated with convenience sampling is that the members of the target population are homogeneous. Although convenient sampling frequently used in quantitative study, it is proven that it could be used in both qualitative and quantitative study. (Etikan et al, 2016).

In Information and Communication Technology, convenient sampling seems to be dominant (Perumal, 2014). In this research, the objective is to analyze the rhetorical of hate speech related to Ahok's religion blasphemy case from the content in various sites that clearly persuading its readers to hate Ahok and his supporters. The content that selected as sample were excluding the content from mainstream online media that trusted and well established because this kind of sites cannot publish content that violating the Law of Journalism and Ethic Code of Journalism.

The sample criteria are: a) Content with provocative hate message written and categorized as news or opinion by the sites administrator. b) Has easy accessibility which means it could be accessed by Internet. c) Available at a given time, which mean the website are unblocked yet by the government at the time researched was conducted. This research also using assumption that the target population could be assumed rather homogenous as all of the hate sites are naturally has the same negative content and provoking hate using race, ethnicity and inter-community or religion.

Based on this criteria, there are 9 samples collected (Table 1).

TABLE 1. Websites Sample

\begin{tabular}{|c|c|c|c|c|}
\hline No & Websites Name & Date Published & Title of the Content & url link \\
\hline 1. & Portal-islam.id & $\begin{array}{l}\text { November, 4, } \\
2016\end{array}$ & $\begin{array}{l}\text { Gila! Pendukung Ahok } \\
\text { Provokasi Aksi } 4 \text { Nov } \\
\text { Dengan Sebar Poster } \\
\text { Editan "Bunuh Ahok Cina } \\
\text { Kafir" } \\
\text { (Copy pasted from } \\
\text { portalpiyungan.com) }\end{array}$ & $\begin{array}{l}\text { http://www.portal- } \\
\text { islam.id/2016/11/ } \\
\text { gila-pendukung- } \\
\text { ahok-provokasi- } \\
\text { aksi-4.html }\end{array}$ \\
\hline 2. & Serupedia.info & $\begin{array}{l}\text { December, 11, } \\
2016\end{array}$ & $\begin{array}{l}\text { Sadar Ahok Sekarat, Sosok } \\
\text { Hary Tanoe Dimunculkan! } \\
\text { "Umat Islam Terkelabuhi, } \\
\text { Ini Dosa Said Agil Siroj! }\end{array}$ & $\begin{array}{l}\text { http://www. } \\
\text { serupedia. } \\
\text { info/2016/12/ } \\
\text { sadar-ahok-sekarat- } \\
\text { sosok-hary-tanoe- } \\
\text { dimunculkan-umat- } \\
\text { islam-terkelabuhi- } \\
\text { ini-dosa-said-agil- } \\
\text { siroj.html }\end{array}$ \\
\hline
\end{tabular}


Kurnia Arofah. Rhetorical Analysis of Hate Speech: Case Study of Hate...

\begin{tabular}{|c|c|c|c|c|}
\hline 3. & $\begin{array}{l}\text { Pribuminews. } \\
\text { com }\end{array}$ & $\begin{array}{l}\text { December, } 14, \\
2016\end{array}$ & $\begin{array}{l}\text { Jawaban Atas Air Mata } \\
\text { dan Nota Pembelaan Sang } \\
\text { Penista Agama Dalam } \\
\text { Sudang Perdana Kasus } \\
\text { Penistaan Agama Oleh } \\
\text { Basuki }\end{array}$ & $\begin{array}{l}\text { https://pribuminews. } \\
\text { co.id/2016/12/14/ } \\
\text { jawaban-atas-air- } \\
\text { mata-dan-nota- } \\
\text { pembelaan-sang- } \\
\text { penista-agama- } \\
\text { dalam-sidang- } \\
\text { perdana-kasus- } \\
\text { penistaan-agama- } \\
\text { oleh-basuki/ }\end{array}$ \\
\hline 4. & Kammilipia.com & $\begin{array}{l}\text { February, } \quad 8, \\
2017\end{array}$ & Kutil Babi & $\begin{array}{l}\text { http://www. } \\
\text { kammilipia. } \\
\text { com/2017/02/kutil- } \\
\text { babi.html?m=0 }\end{array}$ \\
\hline 5. & $\begin{array}{l}\text { Suaranasional. } \\
\text { com }\end{array}$ & March, 2, 2017 & $\begin{array}{lr}\text { Gembong } & \text { Bani } \\
\text { Gunawan } & \text { Merbet } \\
\text { Sebarkan } & \text { Hoax } \\
\text { Pendukungnya } & \text { Mingkem } \\
\text { Semua } & \end{array}$ & $\begin{array}{l}\mathrm{ht} \mathrm{t} \text { s: } \\
\text { suaranasional. } \\
\text { com } / 2017 / 03 / 04 / \\
\text { gembong-bani- } \\
\text { serbet-gunawan- } \\
\text { mo ha m a d - } \\
\text { sebarkan-hoax- } \\
\text { pendukungnya- } \\
\text { mingkem-semua/ }\end{array}$ \\
\hline 6. & $\begin{array}{l}\text { Piyunganonline. } \\
\text { co }\end{array}$ & March, 16, 2017 & $\begin{array}{l}\text { Rizieq: Hary Tanoe BABI, } \\
\text { Ahok Kutil Babi }\end{array}$ & $\begin{array}{l}\text { ht t } \mathrm{p}: / / \mathrm{w} \text { w w } \\
\text { piyunganonline.co/ } \\
\text { read/rizieq-hary- } \\
\text { tanoe-babi-ahok- } \\
\text { kutil-babi.html }\end{array}$ \\
\hline 7 & Nusanews.id & March, 28, 2017 & $\begin{array}{l}\text { Gak Kompak! Bani Taplak } \\
\text { Tak Sepaham Dengan } \\
\text { Junjungannya Soal Syiah }\end{array}$ & $\begin{array}{l}\text { http: // w w w . } \\
\text { nus a n e w s. } \\
\text { id/2017/03/gak- } \\
\text { k o m p a - b a n i- } \\
\text { taplak-tak-sepaham. } \\
\text { html }\end{array}$ \\
\hline 8. & Suluh.co.id & April, 21, 2017 & $\begin{array}{l}\text { Kongkalikong Istana dan } \\
\text { Ahok }\end{array}$ & $\begin{array}{l}\text { http://www.suluh. } \\
\text { co.id/berita-416- } \\
\text { kongkalikong- } \\
\text { istana-dan-ahok. } \\
\text { html }\end{array}$ \\
\hline 9. & $\begin{array}{l}\text { Nahimungkar. } \\
\text { org }\end{array}$ & October, 2017 & $\begin{array}{l}\text { Tidak Terima Polingnya } \\
\text { Kalah, Kecebong Ini Buat } \\
\text { Poling Baru Khusus Untuk } \\
\text { \#IQ200SEKOLAM Saja }\end{array}$ & $\begin{array}{l}\text { https://w w w } \\
\text { nahimunkar.org/ } \\
\text { tidak-terima- } \\
\text { polingnya-kalah- } \\
\text { kecebong-ini-buat- } \\
\text { poling-baru-khusus- } \\
\text { untuk-kelompok- } \\
\text { iq200sekolam-saja/ }\end{array}$ \\
\hline
\end{tabular}



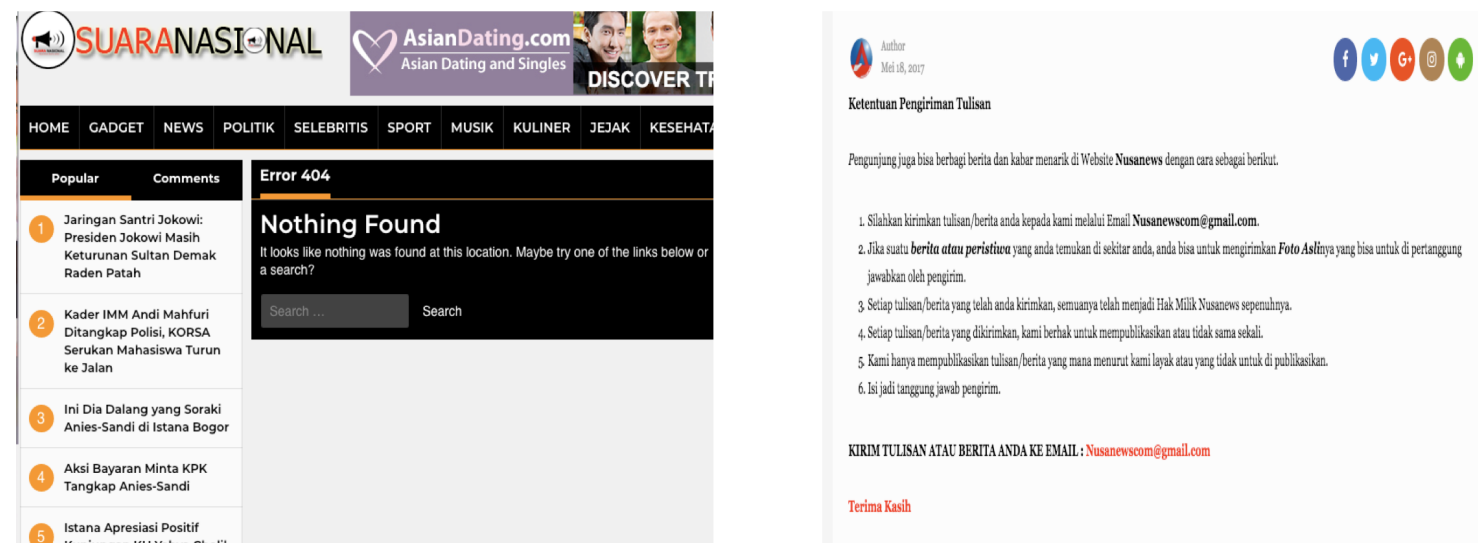

FIGURE 2. The Contact Page from Suaranasional and Nusanews

\section{FINDING \& DISCUSSION}

\section{Ethos Aspect}

Ethos refers to the trustworthiness or credibility of the writer or speaker due to the competent, reliable, fair and frank arguments. It means convincing by the character of an orator (speaker), which lead to persuasion. (Mshvenieradze, 2013). In a writing message, for an argument to be considered credible by readers, they must find it authoritative, believable or trustworthy (Axelrod \& Cooper, 1999).

From all the samples collected, there is some interesting finding in the ethos aspect.. To trace the credibility, one of the way is try find where this content come from. From the entire sample, not all the website are sites that could be categorized as hate sites. For example in kammilipia.org, only one post that contain severe hate speech for Ahok, while other post in this websites could be consider as ordinary and normal posting. From these 9 sites, there are 6 website that owned by unknown. To trace back it trustworthiness and credibility as press company is hard since this 6 website did not announce it address and it caretaker openly through its sites.

6 website among did not provides clear address, editorial board and contact info. 4 sites Such as suaranasional. com; serupedia.info; piyunganonline. co; and suluh.co.id were did not provide any contact. If the reader clicked at the menu contact, they would find nothing. However, 2 other sites, portal-islam.id and nusanews.id also did not provide clear address and editorial board in it sites, but they still providing email address that could be use by the reader.

The rest 3 samples that selected indeed provide really clear address or

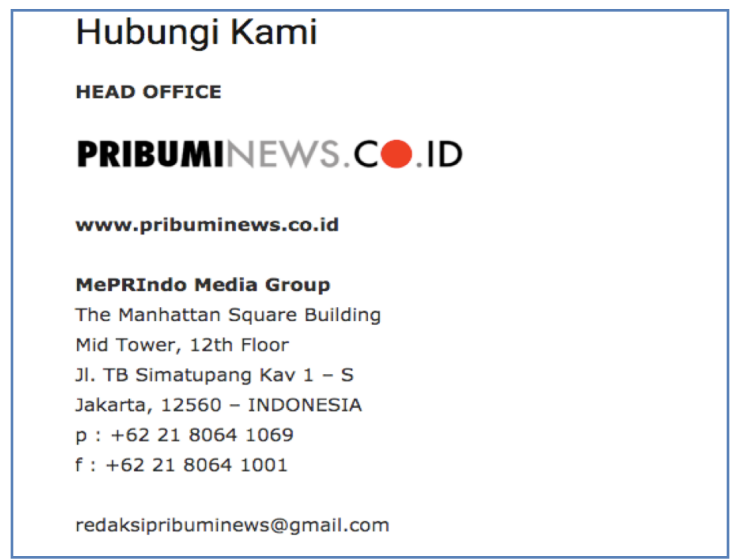

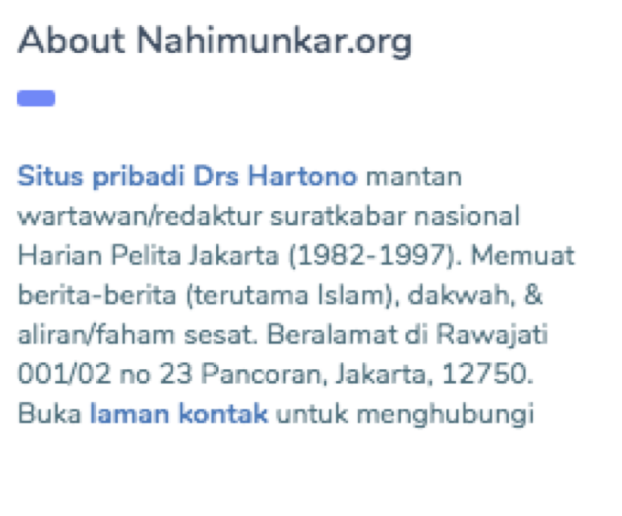

FIGURE 3. The Contact Page from pribuminews.co.id and nahimungkar.org 
Kurnia Arofah. Rhetorical Analysis of Hate Speech: Case Study of Hate...
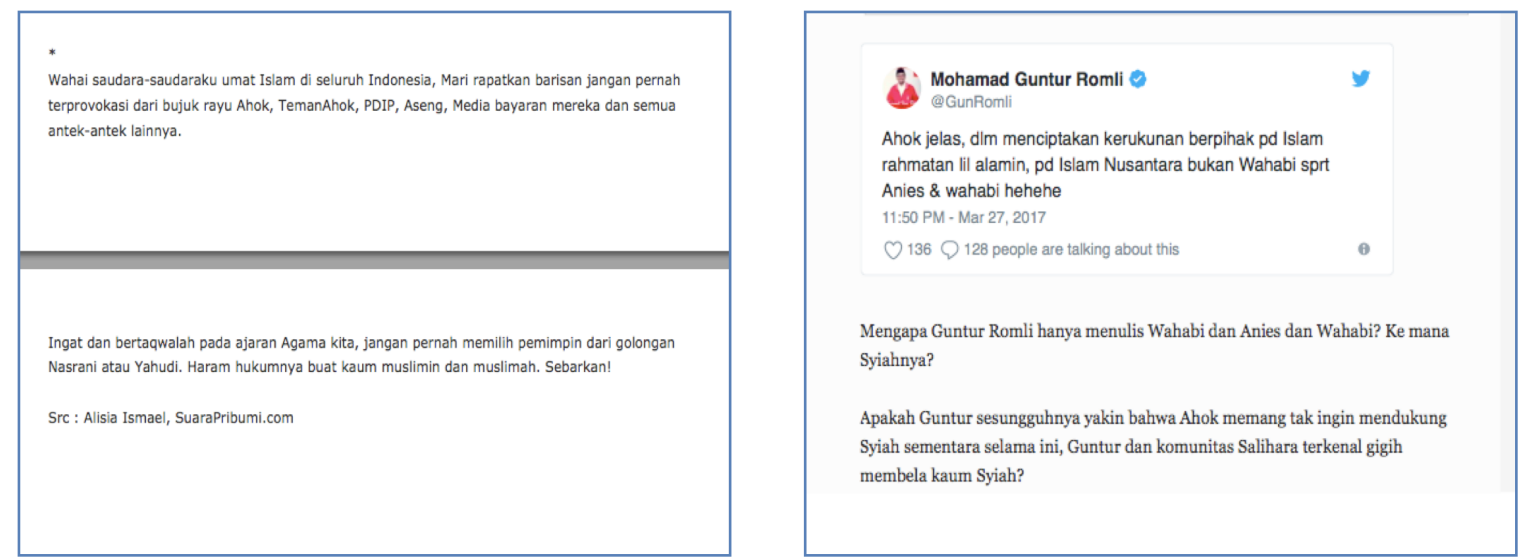

FIGURE 4. Source Use and Quoted by pribuminew.com and nusanews.id

editorial board such as pribuminews.com, nahimunkar.org and kammilipia.com Both pribuminews.co.id and nahimunkar. org were stating clearly who they are and their address. Pribuminews even stated its editorial board and has link menu to cyber journalism ethics. While kammilipia. com did not publishing its address but they have tab menu which shows all the organization structure and its name.

Ethos aspect cannot only be seen from the creator or author only. Ethos is not created or bound to the author, but embedded in the message instead. Ethos can be used to stress the personal credentials and reputation of the writer or cite reliable sources in the writings. Most of the content that selected as sample did not mention who is the author. Mostly were written by admin or editorial. From 9 sample, only 4 website, piyunganonline. co, suluh.co.id, kammilipia.org and serupedia.info, write the name of its author. While content from portalislam.id war reposting the content from portalpiyungan.com.

In an argument, part of the ethos is finding resources where the audience would find it credible and earns reader's respect for quoting sources they consider trustworthy. The author will demonstrate its objectivity by using sources that are widely respected and gathering information from both or many sides of the issue (boundless.com). From all the samples collected, it is almost impossible to find the ethos aspect based on the source quoted in the content. Pribuminews.com took the source from other website and it is unknown whether all the content was pasted from the copied website. Content posted by 3 sites, suluhpedia.co.id, kammilipia.org, and serupedia.info has no source except from the author's opinion. While the rest 5 sites took the source from random twitter and facebook account.

From the sample selected, 5 of them could be considered as political opinion, while the other 4 could be categorized as news. Whether it is in the political opinion or news, almost the entire posting never covered both sides as it only quoting source from one side, Ahok's opposition side. Based on the credibility of the

\footnotetext{
Protektif yang keterlaluan demi melindungi manusia congak yang tidak pernah berkontribusi positif untuk negri ini tentunya. Ahok begitu dia dipanggil atau entah merupakan nama aslinya, tak lebih adalah "Kutil babi" begitu Habib Rizieq menjulukinya. Maka sebagai manusia yang lebih buruk dibandingkan Luhut Binsar Panjaitan yang serba guna itu, Ahok begitu buruk memperlakukan dirinya dan kepentingannya.
}

Dalam segala hal, tentunya orang-orang waras enggan mendekati si kutil tersebut, terkecuali manusia berotak udang. Terlalu sering dan begitu gampang statemen dan platformnya rapuh dan rusak. Sehingga menyerang visi misi manusia penista itu sangat mudah. Ditengah-tengah kebijakan negara yang serba amburadul dan rusak, negri ini bertambah gaduh dengan adanya si ahok dan para pendukungnya. 


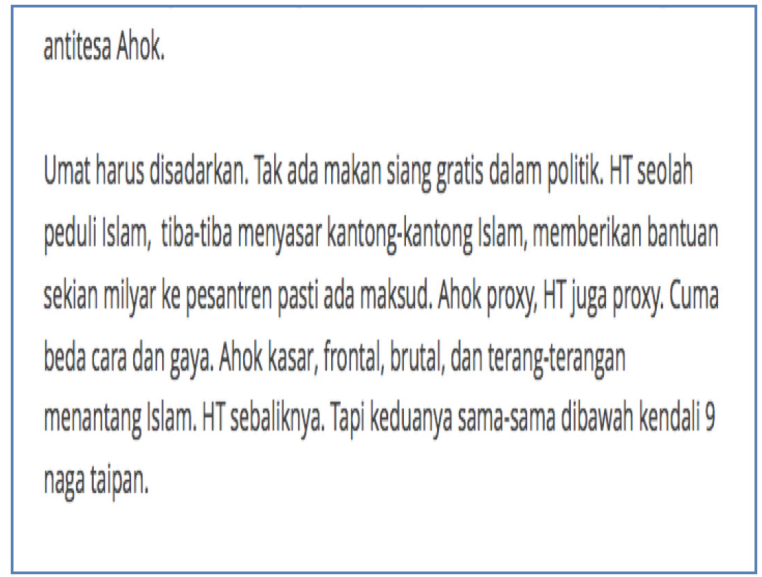

FIGURE 6. Content from Serupedia.info

websites, the author, and the source that cited, the ethos aspect was weak. It means the hate speech in the website content did not use the ethos aspect as the main strength to persuading the reader.

\section{Pathos Aspect}

Pathos is the arousing of emotions in the audience. Pathos relies on evoking emotional reaction from the audience. In writings, this could be done through word choices as by choosing words carefully, author could make subconscious effect on the reader (boundless.com). The concept of pathos could define hate speech since hate speech targets its audience emotions. Among various news values, humaninterest value are the news value that mostly used by news writer to gather and bait the public interest. This news value mostly touches the heart and emotion of audience. This news often used sensation and dramatic claim. Sensation and dramatic claim used to exploit existing feeling of anger, irritation and fear (Nilsen, 2014).

9 of the samples used this kind of emotion appeal to provoke the anger or hate from Ahok supporters or opponents, by exploits anger, and emphasizing the irritating situation caused by Ahok and its supporters.

Translation: too much protection only to protect cocky human who never give positive contribution for this country of course. Ahok, that's how he called or either his real name, is no more than 'pig's warts' thats how Habib Rizieq called him. So, as a human that worse than Luhut Binsar Panjaitan who multipurpose, Ahok is really bad treating him self and his intention. In every thing, of course sane people reluctant to approcing this wart, except human with shrimp brain. Too often and too easy his statement and platform fragile and broken. Thats why attacking the vision and mission

TAPI mereka DIBIARKAN, karena mereka pendukung rezim.

Sedang media yang mendukung dan mem blow up AKSI UMAT ISLAM 4 NOV, langsung DIBLOKIR.

INGAT! Kekuasaan kalian sementara. Kedzoliman pasti akan ada balasannya. Pasti.

FIGURE 5. Content from Serupedia.info 
Kurnia Arofah. Rhetorical Analysis of Hate Speech: Case Study of Hate...

that blasphemer human is very easy. In the middle of government policy that shambles and broken, this country become more crowded with the existence of Ahok and its supporters

In the sample above, the author tries to provoke the anger of Ahok opponents by emphasizing that there are too many things done to protect Ahok while he never contributes to nation. The author also provoke the hate by stating that Ahok is worse than other, and adding much problem with his blasphemy case to the nation that already chaos and unorganized.

The issues about power, selfdetermination, and ethnic identity all come into play when the author tries to provoke the negative emotion of its readers. Hate is about power relationship where the one who's in power want to maintain it, while the one who have no power wants it (Whillock, 2000). The sample by serupedia alluded that Ahok and HT (Hary Tanoe) are proxy under the power of 9-dragon tycoon who have some 'purposes'.

Translation: HT act as if he care about Islam, suddenly targeting Islamic area giving billion grant to pesantren. He must have some purposes. Ahok is proxy, so does HT. Only with different way and style. Ahok is rude, frontal, brutal and clearly opposing Islam, while HT is the opposite. But both is under control of 9 dragon tycoon)
Furthermore, one of the notable elements of hate speech is that it is often so ingrained in us that we don't recognize it (Whillock, 2000).

Translation: But they were allowed because supporting the regime. While media which supporting Muslims action in November 4th directly blocked. Remember, your authority is temporary. There must be punishment for the tyranny. It must be.

Even though this sample rather 'soft' compared to the other, the words used in this sample shows that actually, sometimes we throw a little hate to other people without realize it.

\section{Logos Aspect}

Good arguments always include both fact and reasoning and may be bolstered by examples (www.boundles. com). To put it simple in terms of an argument, logos works as a proof of the messages that is embedded within the message. It includes fact and proofs that, from a scientific point of view, lack the bias that comes from subjectivity (Hansen, 2003).

The 9 samples used in this research are mostly lead to logical fallacy as it conclusion are drawn from the wrong premises, or simply pushing the logical principles without considering it relevance. Logical fallacy also occurs due to the lack of connection between

\section{Lihatlah, orang yang diteriaki Babi dan orang yang meneriaki Babi sekarang \\ duduk bersama bersekutu dengan Anies Baswedan. Mereka bagaikan sekutu atau kawan setia yang disebut dalam tafsir Al Maidah 51 . \\ Peristiwa ini seakan-akan surat Al Maidah sedang di-movie-kan supaya jelas \\ juntrungannya. Sampai disini masih percaya carut marut sekarang ini \\ dikarenakan penodaan agama oleh Ahok ? Pastinya sekarang Wiranto \\ tersenyum, siapa gerangan yang sesungguhnya sedang menjilat pantat cina}

FIGURE 8. Content from piyunganonline.com 


\title{
"Sadar Ahok Sekarat, Sosok Hary Tanoe Dimunculkan!" Umat Islam Terkelabuhi, Ini Dosa Said Agil Siroj!
}

\author{
Sunday, December 11, 2016
}

FIGURE 9. Tittle of Content from serupedia

premises and conclusion. The fact that can't be proven could support the conclusion also lead to logical fallacy.

The first sample from piyungan online make the logical fallacy due to the lack of fact that supports its conclusion:

Translation: Look the people who shout and shouted at now sit together forming Allies with Anis Baswedan. As if they are allies or loyal friend mentioned in the interpretation of $\mathrm{Al}$ Maidah 51. Until now, you still believe the chaotic nowadays caused by Ahok blasphemy?. For sure, now Wiranto is smiling, who is the one who actually licking China's ass

Different with other sample, the sample in figure 6 is not directly aimed to Ahok. Eventhouh the title "Hary Tanoe Babi, Ahok Kutil Babi" seems like aiming Ahok, this sample are attacking Ahok opponents. This conclusion leads the readers to think that Ahok did not cause the chaotic situation in Indonesia. The second conclusion is Wiranto, the current Indonesian Coordinating Minister for Political, Legal, and Security Affairs are laugh at Habib Rizieq due to its political moves. Both conclusions did not draw from premises. As the premises that stated in this news has nothing to do with Ahok as the one who made the situation chaotic. And there is also no prove or fact stated about Wiranto reaction.

The same pattern shows in the sample news from serupedia. The tittle of this news is a conclusion.

Translation: Realize Ahok is dying,
Hari Tanoe figure raised!" Islam people deceived, this is Said Agil Siroj's Sin.

This conclusion drawn without fact as in the body of the news, there is no fact that claims directly about Ahok being 'dying'. More over, there is no single words mention Said Agil Siroj, making the conclusion is nothing to with him. Similar case also occurs in the content by suluh.co.id. In content "Kongkalikong Istana dan Ahok", from the title, he author concludes and accusing the Presidential House, referring to the President for having conspiracy with Ahok. However in the body of the content, there is no proving for this conclusion inside the body of the content

\section{Hate Speech Related to Ahok's Religion Blasphemy Case}

Indonesia is a religious country said the current Indonesian Military Commander, Gen. Gatot Nurmantyo (News Desk, 2017). This statement supporting the previous research data from Gallup in 2009 that shows Indonesia placed in 4th rank position among 114 countries in the world, on the survey about the importance of religion in people daily lives. Based on this data, it is no wonder if anything that related to religion is either sensitive or important, always attracts controversies, giving the fact that Indonesia has 5 religion and many beliefs that admitted by Indonesian Government.

Ahok's religion blasphemy case is one of the biggest religion blasphemy cases in Indonesia because it involves 
almost all elements of society whether they care or not about politic or religion. Almost every mass media and online media proliferates with the content of this case. This blasphemy case along with the Jakarta' governor election might be the most conflicted. Many political opinion, hoaxes and fake news creates uncomforting situation in the Internet (bbc, 2017).

Many netizen in Indonesia often trust these kinds of content from Internet posts more than mass media. Not every reader can distinguish between fact and opinion, and in the end, it drag them into massive logical fallacy. In many cases, especially in a sensitive case such as religion blasphemy that involving Ahok, Indonesian opinion sometimes led and shaped by the postings from this hate content.

Based on the findings, some of the hate speech content is in the political opinion format, and some of them are in news format. This research did not try to prove whether the content of hate speech is fake or true. This research is try to give critical reading to the hate speech and try to unravel how hate speech were use to persuade the readers to hate from the ethos (credibility of the hate speech), pathos (the way hate speech persuades), and logos (the proof or fact given to proof the hate speech).

From the ethos aspect, this research find that not all of the hate speech was posted from the site that cannot be traced back it source. Some of the website even provide the address and editorial board in the sites and not all of the content of each sites were filled with hate. Based on the finding, most of the hate speech did not rely on ethos because the author mostly unknown and the source were taken from social media post such as facebook and twitter. It means, when hate speech spread, it did not emphasize on the credibility aspect.
Hate speech in this research mainly rely heavily on pathos aspect, in this case study, the author acknowledges the pain and anger that people feel and emphasizing it in the content that it was caused by Ahok. The finding shows that logos aspect also neglected as many of the content have logical fallacy. Logical fallacy happen when the conclusion were not backed up by solid an adequate proof. Most of the claimed concluded in the hate speech content did not provide proof of the claim.

The lack of logos normally will lead the readers into logical fallacy as they also fail to draw conclusion from the given fact. Logical fallacy also could happen when the readers were persuades to hate based on the pathos that evoked their emotion and feeling. That's why almost all hate speech in the Ahok's case mostly could ignore the ethos and logos aspect by triggering the hate using pathos aspect. When emotion or feeling play bigger roles, the logic and where the source came from will be neglected.

The phenomena of Ahok's case along side withe the many fake news an hoaxes spreading in the internet is a phenomena that use to be happen in the post truth era. 'Post truth' is the Oxford english dictionary's word of the year 2016. Post truth means an adjective defined as 'relating to or denoting circumstances in which objective facts are less influential in shaping public opinion than appeals to emotion and personal belief (ButlerAdam, 2017)

In this era, the truth is not only under attack, but it's become irrelevant. With the politic, the problem is not so much that it is fake, but because it falsely authentic. Politics used to be conducted through rhetoric. Rhetoric was a tool of persuasion, but only small section of the public schooled in decoding rhetorical techniques (Glaser, 2016). This is why rhetorical analysis is still relevant and 
could be useful in the post truth era especially to analyze hate speech by providing critical reading way. It's not try to seek the truth but rather to find out how the pathos, or the appeal to emotion use in the messages.

\section{CONCLUSION}

Hate speech is something that most rational people don't want to throw to other people. Unfortunately, we didn't realize that sometimes we do throw a little hate to other people in our daily life. Nowadays, the spreading of hate speech is way faster since there is supports from convergence media such as online sites that turn to be hate site.

This research shows that hate speech as the genre of rhetoric always contains three element, ethos, pathos, and logos. In Indonesia, nowadays the hate site is abundant. The recent case that drags Ahok, the candidate of Jakarta's Governor shows that many hate content in the websites uses the elements of rhetoric with malicious intention to provoke negative emotion. This research shows that hate speech mostly neglected the ethos and logos aspect. It rather emphasizes and rely on pathos aspect which provokes the emotion of the audience is the perfect combination of hate speech. This is why rhetorical analysis could be useful to provide critical reading ways in the post truth era.

\section{REFERENCES}

-. (-, - -). Why is Rhetoric Required? Retrieved June 2, 2017, from Collage of Liberal Arts and Sciences The University of Iowa:https://clas.uiowa.edu/rhetoric/ about/why-is-rhetoric-required

-. (-, - -). Why is Rhetoric Required? Retrieved June 2, 2017, from Collage of Liberal Arts and Sciences The University of Iowa: https://clas.uiowa.edu/rhetoric/ about/why-is-rhetoric-required

Agence France-Presse. Jakarta protest : Muslims Turn Out in Force Against
Christian Governor Ahok. Retrieved June 2, 2017 from https://www. theguardian.com/world/2016/dec/02/ jakarta-protests-muslims-againstchristian-governor-ahok

Ambardi, K., Parahita, G., Lindawati, L., Sukarno, A., \& Aprilia, N. (2016). Mapping Digital Media: Indonesia . Open Society Foundation .

APJII. (2016). Penetrasi \& Perilaku Pengguna Internet Indoenesia, Survey 2016. Polling Indonesia \& APJII.

Axelrod, R. B. (1999). Reading Critically, Writing Well: A Reader and Guide. New York: Bedford/St. Martins.

Boundless. (-, - -). Modes of Persuasion: Ethos, Pathos, and Logos. Retrieved June 2, 2017, from boundless. com: https://www.boundless.com/ writing/textbooks/boundless-writingtextbook/writing-an-effectivepaper-235/building-your-paper-239/ modes-of-persuasion-ethos-pathosand-logos-42-7909/

Cohen-Almagor, Raphael. (2011). Fighting Hate and Bigotry on the Internet. Policy \& Internet. Vol.3: Iss.3, Article $6,(1-26)$

Etikan, Ilker., Musa, Sulaiman Abubakar., Alkassim, Rukayya Sunusi. (2016). Comparison of Convenience Sampling and Purposive Sampling. American Journal of Theoretical and Applied Statististics. Vol 5 (1) : 1-4

Flew, T. (2008). New Media. South Melbourne: Oxford University Press

Hansen, B. (2003, October 20). Ethos, Pathos, Logos and the NTSB. Retrieved June 2, 2017, from http://intrans.iastate. edu: http://intrans.iastate.edu/mtc/ documents/studentPapers/2003/Brett Hansen.pdf

International, A. (2014). Prosecuting Beliefs Indonesian's Blasphemy Laws. London: Amnesty International Ltd.

Mshvenieradze, T. (2013). Logos Ethos and Pathos in Political Discourse. Theory and Practice in Language Studies , 3 (9), 1939-1945.

News Desk, J. P. (2017, January 28). Indonesia is a religious country': TNI commander. Retrieved June 2, 2017, from www.thejakartapost. 
Kurnia Arofah. Rhetorical Analysis of Hate Speech: Case Study of Hate...

comm: http://www.thejakartapost. com/news/2017/01/28/indonesia-is-areligious-country-tni-commander.html Nurdin/Zunus. (2016, October 14). Banyak Media Provokatif, Bimas Islam Kemenag Undang Jaringan Media Islam. Retrieved June 2, 2017, from www.nu.or.id: http://www.nu.or. $\mathrm{id} / \mathrm{post} / \mathrm{read} / 72000 /$ banyak-mediaprovokatif-bimas-islam-kemenagundang-jaringan-media-islam

Selzer, Jack. (2004). Rhetorical Analysis : Understanding How Texts Persuade Readers. In Bazerman, Charles., Prior Paul. What Writing Does and How It Does It. (pp. 279-307). New Jersey:
Lawrence Erlbaum Associates, Inc., Publishers

Sternberg, Robert J., Sternberg Karin. (2008). The Nature of Hate. United States of America: Cambridge University Press

Tifa, y. (-, - -). Upaya Deradikalisasi Agama Lewat Media. Retrieved June 2, 2017, from www.tifafoundation.org: http://www.tifafoundation.org/upayaderadikalisasi-agama-lewat-media/

Whillock, R.K.(2000). EthicalConsiderations of Civil Discourse: The Implication of The Rise of "Hate Speech". In R. E. Denton.Jr, Political Communication Ethics An Oxymoron? (pp. 75-90). Westport: Praeger Publisher. 